\title{
EVALUASI KINERJA SISTEM DRAINASE CROSSING JI. RAYA CIBADAK
}

\author{
(Performance Evaluation Of Craining Drainage Crossing Roads In Cibadak) \\ Shova Sara Khaerina ${ }^{1}$, Radius Pranoto ${ }^{2}$, Bambang Jatmika ${ }^{3}$ \\ ${ }^{1,2,3}$ Universitas Nusa Putra
}

Korespondensi Penulis: Kp. Cibatu Nagrak, RT.001/RW.001. Desa Nagrak, Cisaat, Sukabumi

E-mail: shovasara39@gmail.com, radius.pranoto@nusaputra.ac.id,bambang.jatmika@nusaputra.ac.id

Diterima: September 2019; Direvisi: Desember 2019; Disetujui untuk Dipublikasikan: Maret 2020

\begin{abstract}
ABSTRAK
Membahas mengenai banjir di dunia ini memang seperti tidak ada habisnya. Di Indonesia pun banjir sangat populer, khususnya ketika musim penghujan. Peristiwa ini setiap tahun terjadi dan terus berulang. Adanya banjir tersebut karena adanya peningkatan volume air yang mengalir di atas permukaan tanah. Tujuan dilakukannya penelitian ini untuk mengevaluasi kinerja saluran drainase yang telah ada (eksisting) dalam menampung debit air ketika intensitas hujan tinggi.Data curah hujan yang digunakan adalah data curah hujan bulanan 10 tahun terkhir yakni, dari stasiun Cisekarwangi, stasiun Sinagar dan stasiun Cicatih.Analisis distribusi frekuensi dilakukan dengan menggunakan distribusi Normal, Log Normal, Log Pearson III dan distribusi Gumbel. Setelah itu keempat distribusi ini di uji dengan uji Chi-Kuadrat dengan tarif pengujian 0,05 dan menghasilkan distribusi Log Pearson III yang memenuhi syarat, dengan nilai curah hujan sebesar 103,60 mm. Dengan menggunakan rumus Van Breen nilai intensitas curah hujan untuk periode ulang 5 tahun didapatkan sebesar 23,31 mm/jam.Dari penelitian ini didapatkan hasil debit banjir rencana (Qr) sebesar 0,0619 m3/detik sedangkan debit saluran sebesar 0,004875m3/det, artinya Qr>Qs jadi saluran eksisting tidak mampu menampung debit limpasan sehingga perlu mendimensi ulang.
\end{abstract}

Kata Kunci: Drainase Jalan Raya, Debit rencana, Kapasitas Saluran.

\begin{abstract}
Discussing about the floods in this world is like endless. Even in Indonesia floods are very popular, especially during the rainy season. This event occurs every year and continues to repeat. The existence of the flood is due to an increase in the volume of water flowing above the ground surface. The purpose of this research is to evaluate the performance of existing drainage channels in accommodating water discharge when the intensity of rain is high. The rainfall data used is the latest 10 years of monthly rainfall data, from Cisekarwangi Station, Sinagar Station and Cicatih Station. Frequency distribution analysis is performed using the Normal distribution, Normal Log, Pearson Log III and Gumbel distribution. After that the four distributions are tested by Chi-Square test with a 0.05 test rate and produce a Pearson III Log distribution that meets the requirements, with a rainfall value of $103.60 \mathrm{~mm}$. By using the Van Breen formula the value of rainfall intensity for the return period of 5 years is obtained at $23.31 \mathrm{~mm} /$ hour. From this research, the result of the design flood discharge (Qr) is $0.0619 \mathrm{~m} 3 / \mathrm{sec}$ while the channel discharge is $0.004875 \mathrm{~m} 3 / \mathrm{sec}$, meaning that $Q r>Q s$ so that the existing channel is unable to accommodate runoff discharge so it needs to re-dimension.
\end{abstract}

Keywords: Highway Drainage, Discharge plan, Channel Capacity

\section{PENDAHULUAN}

Kecamatan Cibadak merupakan salah satu bagian dari Kabupaten Sukabumi, Jawa Barat dengan luas wilayah 63,15 Ha memiliki 10 kelurahan atau desa. Kecamatan Cibadak mempunyai batasan wilayah antara lain sebelah utara berbatasan dengan Kecamatan Nagrak, sebelah selatan berbatasan dengan Kecamatan Cikembar, sebelah timur berbatasan dengan Kecamatan Cicantayan, sebelah barat berbatasan dengan 
Kecamatan Parungkuda. Dilihat dari segi topografi Kecamatan Cibadak merupakan daratan datar sampai bergelombang yang terletak pada ketinggian $0 \mathrm{~m}-500 \mathrm{~m}$ di atas permukaan laut.

Ketika musim penghujan tiba dengan curah hujan yang tinggi mengakibatkan saluran drainase tidak dapat menampung limpasan air sehingga jalan raya pasar Cibadak tepatnya dekat stasiun kereta sering mengalami genangan air sesaat karena adanya peningkatan debit air, kasus ini terjadi berulang setiap tahunnya, namun permasalahan ini belum dapat diselesaikan. Dari adanya genangan air di jalan raya mengakibatkan kemacetan sehingga sangat mengganggu pengguna jalan dan berdampak juga pada masyarakat sekitar. Tujuan dilakukannya penelitian ini sangat penting dari mengevaluasi kinerja saluran drainase yang telah ada (eksisting) akan mengetahui permasalahan di saluran eksisting tersebut, sehingga dari evaluasi menghasilkan solusi untuk tidak tejadi banjir setiap musim penghujan tiba

\section{METODE PENELITIAN}

\section{Waktu dan Lokasi Penelitian}

Penelitian dilaksanakan di jalan raya Cibadak tepatnya dekat stasiun kereta pada bulan Januari 2019.

\section{Alat dan Bahan}

Peralatan yang digunakan pada penelitian ini adalah seperangkat personal computer yang dilengkapi dengan Microsoft Excel 2013.

Bahan berupa data curah hujan maksimum bulanan di dapatkan dari Dinas Pengelolaan Sumber Daya AirKabupaten Cibadak dari ke tiga Stasiun hujan yaitu Stasiun hujan Cisekarwangi, Stasiun hujan Sinagar dan Stasiun hujan Cicatih. dan data dimensi saluran didapatkan dari Dinas Perumahan dan Kawasan Permukiman.

\section{Prosedur Penelitian dan Analisis Data}

Prosedur analisis data dalam penelitian ini terdiri dari; 1).pengumpulan dan penghitungan data curah hujan, 2) perhitungan debit saluran, 3) periksa daya tampung debit rencana dan debit saluran, dan 4) evaluasi dan rekomendasi solusi. Secara ringkas alur penelitian dijelaskan pada Gambar 1.

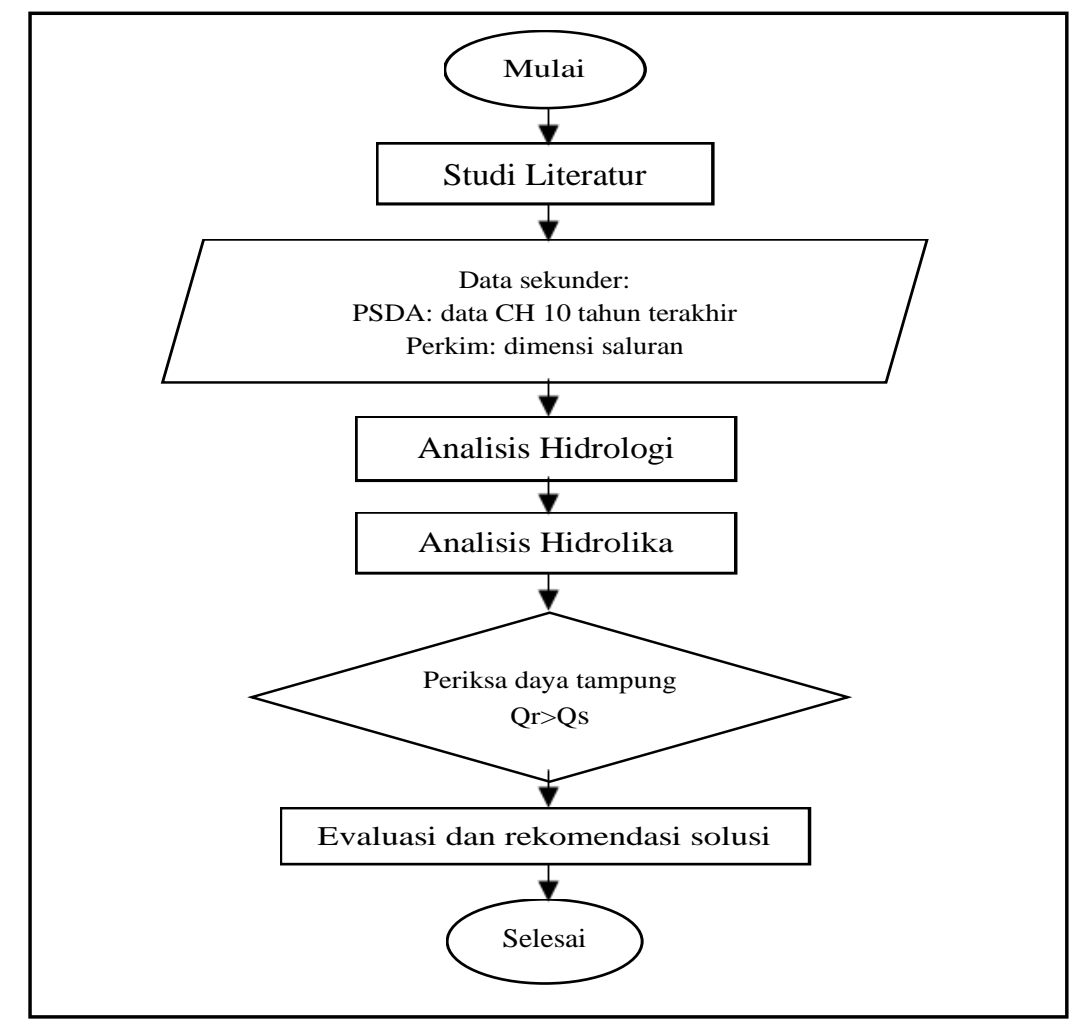

Gambar 1. Diagram alir penelitian 
Selanjutnya mengolah data curah hujan menggunakan rumus rata-rata aljabar

$P=\frac{\mathrm{P} 1+\mathrm{P} 2+\mathrm{P} 3+\cdots+\mathrm{Pn}}{\mathrm{n}}=\frac{\sum_{i=1}^{n} P 1}{n}$.

Dimana: Pn = curah hujan yang tercatat di pos penakar hujan

$\mathrm{N}$ = banyaknya pos penakar hujan

Selanjutnya menghitung ke empat analisis frekuensi distribusi, ada empat macam seri data yang dipergunakan dalam analisis frekuensi, yaitu:
a. Distribusi Normal
b. Distribusi Log Normal
c. Distribusi Log Pearson III
d. Distribusi Gumbel

Dan hanya satu dari ke empat frekuensi distribusi yang memenuhi syarat yang dipakai untuk perhitungan selanjutnya.

\section{Waktu Konsentrasi}

$t_{c}=t_{o}+t_{d}$

\section{Intensitas Hujan}

Dalam SNI 03-3424-1994, Van Breen melakukan penyelidikan bahwa hujan terkonsentrasi selama 4 jam dengan jumlah hujan sebesar $90 \%$ dari jumlah hujan selama 24 jam.

$\mathrm{I}=\frac{90 \% \cdot X t}{4}$

\section{Debit Banjir Rencana (Qr)}

$\mathrm{Q}=\frac{1}{3,60}$ C.I.A.

\section{Koefisien Limpasan (C)}

Koefisien limpasan merupakan nilai banding antara bagian hujan yang membentuk limpasan langsung dengan hujan total yang terjadi (Triatmodjo,2008). Koefisien limpasan dapat dihitung dengan rumus:

$\mathrm{C}=\frac{\sum C_{i} A_{i}}{\sum A_{i}}$

\section{Perhitungan Kecepatan Aliran (V)}

Rumus menghitung kecepatan aliran dalam satuan:

$\mathrm{V}=\frac{1}{n} \cdot \mathrm{R}^{2 / 3} \cdot \mathrm{S}^{1 / 2}$

\section{HASIL DAN PEMBAHASAN}

\section{Analisis Hidrologi}

Analisis hidrologi merupakan suatu proses perhitungan data mentah yang di dapatkan dari Dinas Pengelolaan Sumber Daya Air kabupaten Sukabumi. Data curah hujan maksimum bulanan dari ketiga stasiun pencatat hujan didapatkan. Dari data curah hujan yang didapatkan selanjutya menghitung curah hujan maksimum tahunan daerah dengan menggunakan rumus rata-rata aljabar. Berikut ini contoh perhitungan di bulan Januari sampai Desember 2009: 


$$
\begin{aligned}
& \mathrm{R}=\frac{1}{12}\left(R_{J a n}+R_{F e b}+R_{M a r}+R_{A p r}+R_{M e i}+R_{J u n}+R_{J u l}+R_{A g s}+R_{S e p}+R_{O k t}+R_{N o v}+R_{D e s}\right) \\
& \mathrm{R}=\frac{1}{12}(48.67+48.67+63.67+30.33+42+20+14.33+11+40.33+41.33+51+54.67) \\
& \mathrm{R}=\frac{1}{12} \times 466=38.33 \mathrm{~mm}
\end{aligned}
$$

Dibawah ini adalah hasil perhitungan keseluruhan curah hujan bulanan dan tahunan dari stasiun hujan Cisekarwangi, stasiun hujan Sinagar dan stasiun hujan Cicatih ditampilkan pada Tabel 1-2.

Tabel 1. Data Curah Hujan Tahunan dan Bulanan

\begin{tabular}{|c|c|c|c|c|c|c|c|c|c|c|c|c|c|}
\hline \multirow[b]{2}{*}{ TAHUN } & \multirow[b]{2}{*}{ JAN } & \multirow[b]{2}{*}{ FEB } & \multirow[b]{2}{*}{ MAR } & \multirow[b]{2}{*}{ APR } & \multirow[b]{2}{*}{ MEI } & \multicolumn{2}{|c|}{ BULAN } & \multirow[b]{2}{*}{ AGS } & \multirow[b]{2}{*}{ SEP } & \multirow[b]{2}{*}{ OKT } & \multirow[b]{2}{*}{ NOV } & \multirow[b]{2}{*}{ DES } & \multirow{2}{*}{$\begin{array}{c}\text { CH MAX } \\
\text { THN } \\
\text { DAERAH } \\
\end{array}$} \\
\hline & & & & & & JUN & JUL & & & & & & \\
\hline 2009 & 48,67 & 48,67 & 63,67 & 30,33 & 42,00 & 20,00 & 14,33 & 11,00 & 40,33 & 41,33 & 51,00 & 54,67 & 63,67 \\
\hline 2010 & 34,33 & 78,67 & 68,33 & 31,33 & 67,33 & 96,33 & 55,33 & 35,00 & 53,00 & 69,33 & 59,00 & 73,67 & 96,33 \\
\hline 2011 & 38,33 & 51,33 & 42,33 & 47,33 & 50,33 & 50,00 & 51,00 & 34,67 & 7,33 & 37,67 & 87,33 & 53,00 & 87,33 \\
\hline 2012 & 43,00 & 73,00 & 36,67 & 105,33 & 56,00 & 45,33 & 19,67 & 0,00 & 11,33 & 47,33 & 78,67 & 55,00 & 105,33 \\
\hline 2013 & 72,67 & 84,67 & 60,33 & 64,67 & 55,00 & 41,33 & 71,00 & 35,33 & 28,33 & 66,00 & 51,67 & 45,33 & 84,67 \\
\hline 2014 & 86,67 & 37,33 & 33,33 & 44,67 & 54,33 & 55,33 & 19,00 & 46,67 & 6,00 & 23,00 & 81,67 & 82,67 & 86,67 \\
\hline 2015 & 32,67 & 54,00 & 72,33 & 58,33 & 56,00 & 64,33 & 2,33 & 2,33 & 0,00 & 21,33 & 76,00 & 57,00 & 76,00 \\
\hline 2016 & 64,00 & 43,00 & 58,67 & 66,00 & 69,00 & 69,67 & 69,33 & 55,00 & 89,00 & 70,00 & 84,33 & 49,00 & 89,00 \\
\hline 2017 & 45,33 & 46,67 & 63,33 & 52,67 & 49,33 & 57,33 & 50,00 & 5,67 & 30,00 & 57,00 & 79,67 & 50,67 & 79,67 \\
\hline $\begin{array}{c}2018 \\
\text { MAX }\end{array}$ & 39,33 & 48,33 & 40,67 & 53,00 & 59,33 & 55,33 & 10,33 & 11,33 & 30,33 & 22,00 & 59,67 & 47,67 & 59,67 \\
\hline BLN & 86,67 & 84,67 & 72,33 & 105,33 & 69,00 & 96,33 & 71,00 & 55,00 & 89,00 & 70,00 & 87,33 & 82,67 & \\
\hline
\end{tabular}

\begin{tabular}{cccccccccccccc}
\hline & & \multicolumn{1}{c}{} & \multicolumn{1}{c}{ R } \\
TAHUN & JAN & FEB & MAR & APR & MEI & JUN & JUL & AGS & SEP & OKT & NOV & DES \\
\hline 2009 & 48,67 & 48,67 & 63,67 & 30,33 & 42,00 & 20,00 & 14,33 & 11,00 & 40,33 & 41,33 & 51,00 & 54,67 & $\mathbf{3 8 , 3 3}$ \\
2010 & 33,33 & 78,67 & 68,33 & 31,33 & 67,33 & 96,33 & 55,33 & 35,00 & 53,00 & 69,33 & 59,00 & 73,67 & $\mathbf{6 0 , 1 4}$ \\
2011 & 38,33 & 51.33 & 42,33 & 47,33 & 50,33 & 50,00 & 51,00 & 34,67 & 7,33 & 37,67 & 87,33 & 53,00 & $\mathbf{4 5 , 8 9}$ \\
2012 & 43,00 & 73,00 & 36,67 & 105,33 & 56,00 & 45,33 & 19,67 & 0,00 & 11,33 & 47,33 & 78,67 & 55,00 & $\mathbf{4 7 , 6 1}$ \\
2013 & 72,67 & 84,67 & 60,33 & 64,67 & 55,00 & 41,33 & 71,00 & 35,33 & 28,33 & 66,00 & 51,67 & 45,33 & $\mathbf{5 6 , 3 6}$ \\
2014 & 86,67 & 37,33 & 33,33 & 44,67 & 54,33 & 55,33 & 19,00 & 46,67 & 6,00 & 23,00 & 81,67 & 82,67 & $\mathbf{4 7 , 5 6}$ \\
2015 & 32,67 & 54,00 & 72,33 & 58,33 & 56,00 & 64,33 & 2,33 & 2,33 & 0,00 & 21,33 & 76,00 & 57,00 & $\mathbf{4 1 , 3 9}$ \\
2016 & 64,00 & 43,00 & 58,67 & 66,00 & 69,00 & 70,00 & 69,33 & 55,00 & 89,00 & 70,00 & 84,33 & 49,00 & $\mathbf{6 5 , 6 1}$ \\
2017 & 45,33 & 46,67 & 63,00 & 52,67 & 49,00 & 57,33 & 50,00 & 5,67 & 30,00 & 57,00 & 79,67 & 50,67 & $\mathbf{4 8 , 9 4}$ \\
2018 & 39,33 & 44,00 & 40,67 & 53,00 & 59,33 & 55,33 & 10,33 & 11,33 & 30,33 & 22,00 & 59,67 & 47,67 & $\mathbf{3 9 , 4 2}$ \\
R bln & $\mathbf{5 0 , 5 0}$ & $\mathbf{5 6 , 1 3}$ & $\mathbf{5 3 , 9 3}$ & $\mathbf{5 5 , 3 7}$ & $\mathbf{5 5 , 8 7}$ & $\mathbf{5 5 , 5 3}$ & $\mathbf{3 6 , 2 3}$ & $\mathbf{2 3 , 7 0}$ & $\mathbf{2 9 , 5 7}$ & $\mathbf{4 5 , 5 0}$ & $\mathbf{7 0 , 9 0}$ & $\mathbf{5 6 , 8 7}$ & \\
\hline
\end{tabular}

Tabel 2. Data Curah Hujan Maksimum Tahunan Daerah

Salah satu contoh perhitungan rata-rata curah hujan maksimum pertahun adalah:

$\mathrm{R}=\frac{1}{3}$ (R Cisekarwangi $+\mathrm{R}$ Sinagar $+\mathrm{R}$ Cicatih $)$

$\mathrm{R}=\frac{1}{3}(77+68+87)$

$\mathrm{R}=77,33 \mathrm{~mm}$

Berdasarkan contoh perhitungan rata-rata diatas secara keseluruhan dihitung. Hasil perhitungan rata-rata curah hujan daerah dari ke tiga stasiun hujan dalam jangka waktu 2009-2018 ditampilkan pada Tabel 3. 
(Shova Sara Khaerina) | J-TESLINK 1 (2); 27-34 ISSN 2715-4831 cetak; ISSN 2715-6141 online

Tabel 3. Rata-rata Curah Hujan Tahunan Daerah Dari Ke Tiga Stasiun Curah Hujan

\begin{tabular}{rcccc}
\hline TAHUN & St. CISEKARWANGI & St. SINAGAR & St. CICATIH & CH MAKS \\
\hline 2009 & 77 & 68 & 87 & 77.33 \\
2010 & 105 & 106 & 121 & 110.67 \\
2011 & 69 & 82 & 111 & 87.33 \\
2012 & 105 & 104 & 107 & 105.33 \\
2013 & 102 & 93 & 101 & 98.67 \\
2014 & 63 & 98 & 141 & 100.67 \\
2015 & 93 & 73 & 75 & 80.33 \\
2016 & 94 & 92 & 106 & 97.33 \\
2017 & 70 & 64 & 105 & 79.67 \\
2018 & 66 & 55 & 55 & 58.67 \\
& & & $\sum$ & 896.00 \\
\hline
\end{tabular}

Setelah mengetahui hasil rata-rata curah hujan di ketiga stasiun itu, selanjutnya di urutkan, dari nilai terkecil atau dari nilai terbesar. Perhitungan ini dipakai untuk menganalisis Frekuensi dan Probabilitas.

Tabel 4. Perhitungan Log Pearson III

\begin{tabular}{ccccccc}
\hline Tahun & Xi & LOG Xi & $\log X i-\log X$ & $(\log X i-\log X)^{\wedge} 2$ & $(\log X i-\log X)^{\wedge} 3$ & $(\log X i-\log X)^{\wedge} 4$ \\
\hline 2010 & 110.67 & 2.04 & 0.10 & 0.0097 & 0.0010 & 0.000094 \\
2012 & 105.33 & 2.02 & 0.08 & 0.0059 & 0.0005 & 0.000035 \\
2014 & 100.67 & 2.00 & 0.06 & 0.0033 & 0.0002 & 0.000011 \\
2013 & 98.67 & 1.99 & 0.05 & 0.0024 & 0.0001 & 0.000006 \\
2016 & 97.33 & 1.99 & 0.04 & 0.0018 & 0.0001 & 0.000003 \\
2011 & 87.33 & 1.94 & 0.00 & 0.0000 & 0.0000 & 0.00000000039 \\
2015 & 80.33 & 1.90 & -0.04 & 0.0017 & -0.0001 & 0.000003 \\
2017 & 79.67 & 1.90 & -0.04 & 0.0020 & -0.0001 & 0.000004 \\
2009 & 77.33 & 1.89 & -0.06 & 0.0033 & -0.0002 & 0.000011 \\
2018 & 58.67 & 1.77 & -0.18 & 0.0314 & -0.0056 & 0.000986 \\
\hline
\end{tabular}

1. Rata-rata Curah hujan (X)

$\begin{aligned} \log X & =\frac{\sum_{i}^{n}=1 \log X i}{n}=\frac{19.46}{10}=1.95 \mathrm{~mm} \\ X & =10^{1.95}=88.23 \mathrm{~mm}\end{aligned}$

2. Standar Deviasi (S)

$\mathrm{S}=\left[\frac{\sum_{i=1}^{n}(\log X i-\log X)}{n-1}\right] 0.5=\left[\frac{0.17}{9}\right] 0.5=0.08 \mathrm{~mm}$

3. Koefisien Variasi $(\mathrm{Cv})$

$$
\mathrm{Cv}=\frac{S}{\log X}=\frac{0.0094}{1.95}=0.04 \mathrm{~mm}
$$

4. Koefisien Skewness (Cs)

$$
\mathrm{Cs}=\frac{n x \sum(X i-X)^{3}}{9 \times 8 \times S^{3}}=\frac{10 \times(-0.0041)}{9 \times 8 \times 0.08^{3}}=-1.015 \mathrm{~mm}
$$

5. Koefisien Kurtosis (CK)

$$
\mathrm{CK}=\frac{n \times \sum(X i-X)^{4}}{9 \times 8 \times 7 \times S^{4}}=\frac{10 \times 0.0012}{9 \times 8 \times 7 \times 0.08^{4}}=4.91 \mathrm{~mm}
$$

6. Koefisien Kemencengan $(\mathrm{G})$

$$
\mathrm{Cs}=\frac{n x \sum(X i-X)^{3}}{9 \times 8 \times S^{3}}=\frac{10 \times(-0.0041)}{9 \times 8 \times 0.08^{3}}=-1.015 \mathrm{~mm}
$$


Didapatkan koefisien kemencengan $(\mathrm{G})$ sebesar -1.015, maka nilai tabel harga $\mathrm{T}$ bisa dicari dengan menggunakan interpolasi. Berikut ini table koefisien $\mathrm{G}$ dengan nilai $\mathrm{K}$ :

Tabel 5. Nilai K Koefisien Kemencengan (G) Periode Ulang (T)

\begin{tabular}{ccc}
\hline $\mathrm{T}$ & Koef $\mathrm{G}$ & nilai $\mathrm{K}$ \\
\hline 2 & -1.015 & 0.192675 \\
5 & -1.015 & 0.8446 \\
10 & -1.015 & 1.08915 \\
25 & -1.015 & 1.2883 \\
50 & -1.015 & 1.387475 \\
\hline
\end{tabular}

Sumber: perhitungan

Setelah menghitung nilai $\mathrm{K}$ dengan periode ulang 2, 5, 10, 25 dan 50 tahun, selanjutnya menghitung frekuensi curah hujan dengan rumus Log Pearson III

$\log X_{T}=\log X+K . S$

Berikut ini perhitungan Log Pearson dengan periode ulangnya:

a. $\log X_{2}=1.95+(0.192675 \times 0.08)=1.96$

$$
X^{1.96}=91.52 \mathrm{~mm}
$$

b. $\quad \log X_{5}=1.95+(0.8446 \times 0.08)=2.02$

$X^{2.02}=103.599 \mathrm{~mm}$

c. $\quad \log X_{10}=1.95+(1.08915 x 0.08)=2.04$

$X^{2.04}=108.53 \mathrm{~mm}$

d. $\log X_{25}=1.95+(1.2883 x 0.08)=2.05$

$X^{2.05}=112.72 \mathrm{~mm}$

e. $\log X_{50}=1.95+(1.387475 x 0.08)=2.06$

$X^{2.06}=114.87 \mathrm{~mm}$

Tabel 6. Hasil nilai curah hujan rencana (Xtr) dari ke empat distribusi frekuensi

\begin{tabular}{ccccc}
\hline $\begin{array}{c}\text { periode } \\
\text { ulang }(\mathrm{T})\end{array}$ & Normal $(\mathrm{mm})$ & Log Normal $(\mathrm{mm})$ & Log Pearson $(\mathrm{mm})$ & gumbel $(\mathrm{mm})$ \\
\hline 2 & 89.6 & 88.23 & 91.52 & 87.46 \\
5 & 102.89 & 103.51 & 103.60 & 106.35 \\
10 & 109.85 & 112.54 & 108.53 & 118.85 \\
25 & 116.65 & 122.13 & 112.72 & 134.65 \\
50 & 122.03 & 130.29 & 114.87 & 146.37 \\
\hline
\end{tabular}

Sumber: perhitungan

Tabel 7. Nilai Uji Dispersi Distribusi Frekuensi

\begin{tabular}{ccccc}
\hline No & jenis distribusi & Syarat & perhitungan & ket \\
\hline 1 & Normal & $\mathrm{CS}=0$ & -0.6107 & tidak memenuhi \\
& & $\mathrm{CK}=3$ & 3.92 & tidak memenuhi \\
\hline 2 & Log Normal & $\mathrm{Cs} \mathrm{Cv} 3+3 \mathrm{Cv}=0,162$ & -1.015 & tidak memenuhi \\
& & $\mathrm{Ck}=\mathrm{Cv} 3+6 \mathrm{Cv} 6+15 \mathrm{Cv} 4+16 \mathrm{Cv} 6+3=$ & & \\
& & 3,047 & -1.91 & tidak memenuhi \\
\hline 3 & Log Pearson III & $\mathrm{Cs}=0$ & 4.91 & Memenuhi \\
& & $\mathrm{Ck}=0$ & -0.6107 & Memenuhi \\
\hline 4 & Gumbel & $\mathrm{Cs}=1,14$ & 3.92 & tidak memenuhi \\
& & $\mathrm{Ck}=5,4$ & & \\
\hline
\end{tabular}

Sumber: perhitungan 


\section{Uji Chi Kuadrat Log Pearson III}

Pengujian ini bertujuan untuk menentukan apakah data yang telah dipilih sudah memenuhi syarat untuk digunakan dalam analisis lebih lanjut. Penentuan keputusan ini dapat dihitung menggunakan rumus:

$X_{h}^{2}=\sum_{i-1}^{G} \frac{(O i-E i)^{2}}{E i}$

Jumlah kelas distribusi dihitung dengan rumus:

$\mathrm{G}=1+3,322 \log \mathrm{n}$

$\mathrm{G}=1+3,322 \log 10$

$\mathrm{G}=4,322 \approx 4$

Derajat kebebasan $(\mathrm{Dk})=\mathrm{G}-\mathrm{R}-1$ (nilai $\mathrm{R}$ adalah 2 (sumber: Suripin))

$\mathrm{Dk}=4-2-1=1$

Jumlah nilai teoritis $(\mathrm{Ei})=\frac{n}{G}$

$\mathrm{Ei}=\frac{10}{4}=2,5$

$D_{x}=\frac{(\text { Xmaks }- \text { Xmin })}{(G-1)}$

$D_{x}=\frac{(110,67-58,67)}{(4-1)}=17,33$

Xawal $=$ Xmin $-\left(0,5 \times D_{x}\right)=58,67-(0,5 \times 17,33)=50.005$

Tabel 8. Nilai Uji Chi Kuadrat Log Pearson III

\begin{tabular}{cccccc}
\hline Kelas & Interval & oi & Ei & $(\text { oi-ei })^{2}$ & (oi-ei) $)^{2} / \mathrm{ei}$ \\
\hline 1 & $50,005-67,338$ & 4 & 2.5 & 2.25 & 0.9 \\
2 & $67,338-84,671$ & 2 & 2.5 & 0.25 & 0.1 \\
3 & $84,671-102,005$ & 2 & 2.5 & 0.25 & 0.1 \\
4 & $102,005-119,338$ & 2 & 2.5 & 0.25 & 0.1 \\
\hline \multicolumn{7}{c}{} & $\sum$ & 10 & 10 & & 1,2 \\
\hline
\end{tabular}

Sumber: perhitungan

Dengan menggunakan taraf nyata pengujian $(\alpha)=0,05$ atau setara dengan 5\% dan DK 1 yang tertera pada

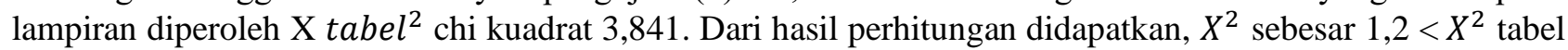
3,84 , sehingga dapat dipsimpulkan bahwa metode distribusi frekuensi log pearson III memenuhi syarat.

\section{Analisis Intensitas Hujan (I)}

Dalam tata cara perencanaan drainase permukaan jalan ( SNI 03-3424-1994 ) ditentukan berdasarkan penyelidikan Van Breen, bahwa hujan harian terkonsentrasi selama 4 jam dengan jumlah hujan sebesar $90 \%$ dari jumlah hujan selama 24 jam,

$I=\frac{90 \%+X \operatorname{tr}}{4}$

Tabel 9. Hasil Perhitungan Intensitas Hujan

\begin{tabular}{ccc}
\hline Tahun & Xtr & Intensitas (mm/jam) \\
\hline 2 & 91.52 & 20.59 \\
5 & 103.60 & 23.31 \\
10 & 108.53 & 24.42 \\
25 & 112.72 & 25.36 \\
50 & 114.87 & 25.85 \\
\hline
\end{tabular}

Sumber: Perhitungan

\section{Waktu Konsentrasi (tc)}

Adalah waktu yang dibutuhkan saat air hujan pada titik awal hulu sampai pada titik saluran. Terlebih dahulu menghitung kemiringan dari hulu ke hilir dari saluran terjauh $\left(\mathrm{t}_{1}\right)$, yaitu : 
Menghitung kemiringan $: S=\frac{\text { titik terjauh-titik terdekat }}{\text { panjang saluran hulu sampai hilir }} \times 100 \%$

$$
\begin{aligned}
& S=\frac{412,5-375}{502} \times 100 \% \\
& S=0,07 \\
& t_{c}=t_{1}+t_{2}
\end{aligned}
$$

$\mathrm{t}_{\text {(aspal) }}=\left[\frac{2}{3} \times 3,28 \times 4,5 \times \frac{0.013}{\sqrt{0.07}}\right]^{0,167}=0,88$ menit

$\mathrm{t}_{\text {(trotoar) }}=\left[\frac{2}{3} \times 3,28 \times 1,5 \times \frac{0.013}{\sqrt{0.07}}{ }^{0,167}=0,73\right.$ menit

$\mathrm{t}_{\text {(perumahan) }}=\left[\frac{2}{3} \times 3,28 \times 8 \times \frac{0.013}{\sqrt{0.07}}\right]^{0,167}=0,97$ menit

$\mathrm{t}_{\text {(jalur hijau, tanah })}=\left[\frac{2}{3} \times 3,28 \times 12 \times \frac{0.013}{\sqrt{0.07}}\right]^{0,167}=1,04$ menit

Waktu untuk mencapai inlet saluran $\left(\mathrm{t}_{2}\right)$ sepanjang $\mathrm{L}$ dari ujung saluran sebagai berikut:

$\mathrm{t}_{2}=\frac{L}{60 \times v}=\frac{502}{60 \times 1,5}=5,57$ menit

Waktu konsentrasi $\left(t_{c}\right)$ total dari waktu pencapaian awal saluran dan waktu pencapaian inlet yang didapatkan sebagai berikut:

$\mathrm{t}_{\mathrm{c}}=\mathrm{t}_{1}+\mathrm{t}_{2} 9.19$

$\mathrm{t}_{\mathrm{c}}=3,62+5,57=9,19$ menit

\section{Luas A dan Koefisien Pengaliran ( C )}

Dalam penelitian sistem drainase jalan raya ini, koefisien pengaliran ( C ) mengacu pada SNI 03-34241994 tentang tata cara perencanaan dra inase permukaan jalan raya, didapatkan nilai koefisien pengaliran ( C ) untuk menghubungkan kondisi permukaan tanah tertentu, yaitu:

1. Koefisien $\mathrm{C}_{1}$ (jalan beton dan beraspal) $=0,95$

2. Koefisien $\mathrm{C}_{2}$ (trotoar) $=0,85$

3. Koefisien $\mathrm{C}$ (perumahan) $=0,60$

4. Koefisien $\mathrm{C}_{4}$ (jalur hijau) $=0,70$ berikut:

Sementara untuk perencanaan luas daerah aliran untuk jalan raya dihitung dengan perhitungan sebagai

Luas $\mathrm{A}_{1}$ (jalan beton beraspal) $=4,5 \mathrm{~m} \times 502 \mathrm{~m}=2259 \mathrm{~m}^{2}$

Luas $\mathrm{A}_{2}$ (trotoar) $=1,5 \mathrm{~m} \times 502 \mathrm{~m}=753 \mathrm{~m}^{2}$

Luas $\mathrm{A}_{3}$ (perumahan) $=8 \mathrm{~m} \times 502 \mathrm{~m}=4016 \mathrm{~m}^{2}$

Luas $\mathrm{A}_{4}$ (jalur hijau atau tanah) $=12 \mathrm{~m} \times 520 \mathrm{~m}=6240 \mathrm{~m}^{2}$

Jadi, luas total pada per hitungan ini adalah $13268 \mathrm{~m}^{2}$

Selanjutnya menghitung nilai koefisien gabungan $\left(\mathrm{C}_{\mathrm{w}}\right)$ yang perhitungannya sebagai berikut:

$\mathrm{C}_{\mathrm{w}}=\frac{(C 1 \times A 1)+(C 2 \times A 2)+(C 3 \times A 3)+(C 4+A 4)}{A 1+A 2+A 3+A 4}$

$\mathrm{C}_{\mathrm{W}}=\frac{(0,95 \times 2259)+(0,85 \times 753)+(0,60 \times 4016)+(0,70 \times 6240)}{2259+753+4016+6240}$

$\mathrm{C}_{\mathrm{w}}=\frac{2146,05+640,05+2409,6+4368}{13268}$

$\mathrm{C}_{\mathrm{w}}=0,72$

Jadi, koefisien pengaliran gabungan C sebesar 0.72

\section{Perhitungan Debit Rencana $\left(Q_{r}\right)$}

Perhitungan debit banjir rencana dalam penelitian ini menggunakan metode debit banjir rasional dengan periode ulang 5 tahun sesuai ketentuan jalan raya. 
$\mathrm{Q}_{\mathrm{r}}=\frac{1}{3,60}$ C.I.A (satuan $\mathrm{km}^{2}$ )

Dari perhitungan sebelumnya sudah didapatkan nilai koefisien pengaliran ( C ) 0.713265 nilai intensitas curah hujan (I) $23.31 \mathrm{~mm} / \mathrm{jam}$ dengan periode ulang 5 tahun dan luas aliran ( A ) $13268 \mathrm{~m}^{2}$.

Jadi, debit banjir rencana dengan periode ulang 5 tahun adalah:

$\mathrm{Q}_{\mathrm{r}}=\frac{1}{3,60}$ C.I.A

$\mathrm{Q}_{\mathrm{r}}=0.278 \times 0,72 \times 23,31 \times 0.013268$

$\mathrm{Q}_{\mathrm{r}}=0,0619 \mathrm{~m}^{3} /$ detik

\section{Analisis Hidrolika}

Analisis hidrolika bertujuan untuk mengetahui kemampuan penampang dalam menampung debit air oleh saluran drainase dengan panjang sebesar $502 \mathrm{~m}$.

\section{Perhitungan Kecepatan Aliran (V)}

Rumus menghitung kecepatan aliran dalam saluran:

$\mathrm{V}=\frac{1}{n} \cdot \mathrm{R}^{2 / 3} \cdot \mathrm{S}^{1 / 2}$

Untuk memperoleh nilai radius Hidrolik (R) dibutuhkan nilai luas penampang dan keliling basah. Luas penampang (A) menggunakan rumus sebagai berikut:

$\mathrm{A}=\frac{1}{8}(\varnothing-\sin \emptyset) \mathrm{r}^{2}$

$\mathrm{A}=\frac{1}{8}(0,4-\sin 0,4) 0,2^{2}$

$\mathrm{A}=0,00195 \mathrm{~m}^{2}$

Keliling basah (P) didapatkan dengan rumus sebagai berikut:

$\mathrm{P}=\frac{1}{2} \cdot \varnothing \cdot \mathrm{d}$

$\mathrm{P}=\frac{1}{2} \times 0,4 \times 0,2$

$\mathrm{P}=0,04 \mathrm{~m}$

Dapat dihitung nilai rumus jari-jari hidraulik penmapang (R) sebesar:

$\mathrm{R}=\frac{1}{4}\left(1 \cdot \frac{\sin \varnothing}{\varnothing}\right) \cdot \mathrm{d}$

$\mathrm{R}=\frac{1}{4}\left(1 \cdot \frac{\sin 0,4}{0,4}\right) \cdot 0,2$

$\mathrm{R}=0,049 \mathrm{~m}$

Untuk tinggi jagaan saluran (freeboard) sebesar:

$\mathrm{W}=\sqrt{0,5} \cdot \mathrm{h}=\sqrt{0,5} \times 0,2=0,1414 \mathrm{~m}$

Maka, kecepatan aliran (V) untuk saluran drainase adalah:

$\mathrm{V}=\frac{1}{n} \cdot \mathrm{R}^{2 / 3} \cdot \mathrm{S}^{1 / 2}$

$\mathrm{V}=\frac{1}{0,014} \times 0,049^{2 / 3} \times 0,07^{1 / 2}$

$\mathrm{V}=2,5 \mathrm{~m} / \mathrm{det}$ 
Dari perhitungan di atas didapatkan kecepatan aliran sebesar 2,5 m/detik. Selanjutnya, kecepatan aliran ini di pakai untuk perhitungan debit saluran.

\section{Perhitungan Daya Tampung Debit Saluran}

Daya tampung debit saluran dapat dihitung dengan rumus sebagai berikut:

$\mathrm{Qs}=\mathrm{V} . \mathrm{A}=2,5 \times 0,00195=0,004875 \mathrm{~m}^{3} / \mathrm{det}$

Perbandingan antara debit banjir rencana dan debit saluran adalah Qr $<$ Qs $=$

Qr $=0,0619 \mathrm{~m}^{3} /$ detik $>$ Qs $=0,004875 \mathrm{~m}^{3} /$ det.

Dari perhitungan di atas membuktikan bahwa saluran eksisting sudah tidak mampu menampung debit banjir rencana. Salah satu permasalahannya adalah kurangnya dimensi saluran untuk menampung limpasan. Selain itu juga pada saluran eksisting terdapat banyak sampah. Sebagai salah satu rekomendasi solusi untuk mengevaluasi kinerja system drainase crossing jalan raya Cibadak adalah memperbesar dimensi saluran supaya tidak terjadi banjir.

\section{Rekomendasi Solusi}

Dari hasil mengevaluasi kinerja sistem drainase crossing di jalan raya Cibadak, penulis merekomendasikan solusi dengan cara memperbesar dimensi saluran drainase yang ada. Data yang didapatkan dari Dinas Perumahan dan Kawasan Permukiman dimensi saluran yang dipakai berdiameter $\varnothing 40 \mathrm{~cm}$ atau 0,4 m sedangkan penulis memperbesar dimensinya dengan diameter $\varnothing 150 \mathrm{~cm}$ atau 1,5 meter. Berikut ini dasil perhitungannya:

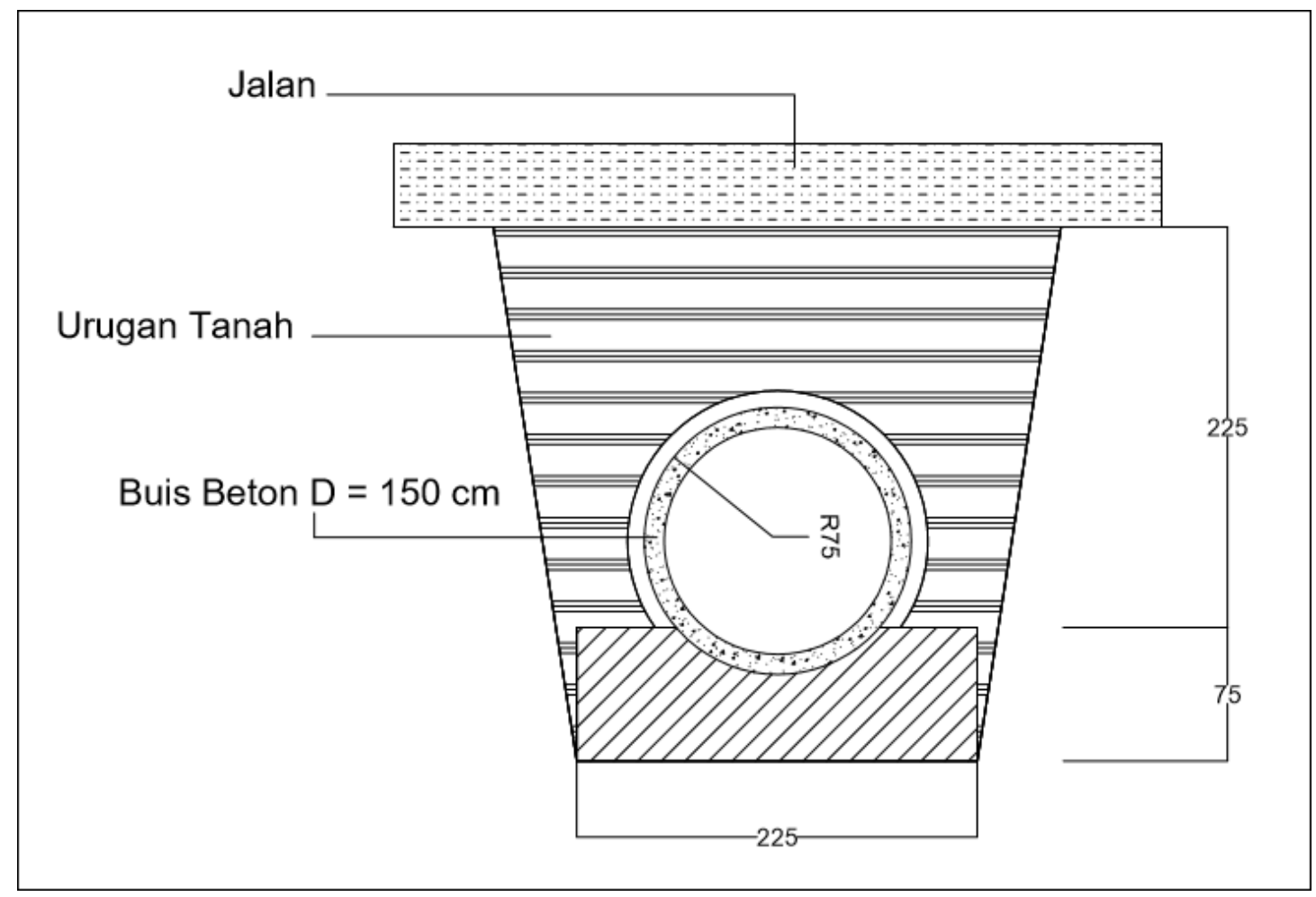

Gambar 2. Dimensi rekomendasi solusi

Luas penampang (A)

$A=\frac{1}{8}(\varnothing-\sin \varnothing) \cdot r^{2}$

$A=\frac{1}{8}(1,5-\sin 1,5) \times 0,75^{2}$ 
$\mathrm{A}=0,092 \mathrm{~m}^{2}$

Keliling basah $(\mathrm{P})$

$\mathrm{P}=\frac{1}{2} \cdot \varnothing \cdot \mathrm{d}$

$\mathrm{P}=\frac{1}{2} \times 1,5 \times 0,75$

$\mathrm{P}=0,5625 \mathrm{~m}$

Jari-jari hidraulik penampang

$\mathrm{R}=\frac{1}{4}\left(1 \cdot \frac{\sin \varnothing}{\varnothing}\right) \cdot \mathrm{d}$

$\mathrm{R}=\frac{1}{4}\left(1 \cdot \frac{\sin 1,5}{1,5}\right) \times 0,75$

$\mathrm{R}=\frac{1}{4}\left(1 \cdot \frac{0,026}{1,5}\right) \times 0,75$

$\mathrm{R}=\frac{1}{4} \times 0,98 \times 0,75$

$\mathrm{R}=\frac{1}{4} \cdot 0,736$

$\mathrm{R}=0,184 \mathrm{~m}$

Maka, kecepatan aliran (V) untuk saluran drainase adalah:

$\mathrm{V}=\frac{1}{n} \cdot \mathrm{R}^{2 / 3} \cdot \mathrm{S}^{1 / 2}$

$\mathrm{V}=\frac{1}{0,014} \cdot 0,184^{2 / 3} \cdot 0,07^{1 / 2}$

$\mathrm{V}=6,09 \mathrm{~m}$

Untuk Q saluran adalah:

$\mathrm{Q}_{\mathrm{s}}=\mathrm{V} \cdot \mathrm{A}=6,09 \cdot 0,092=0,56 \mathrm{~m}^{3} /$ det.

\section{Kesimpulan}

Dapat disimpulkan bahwa penyebab terjadinya banjir adalah dimensi saluran yang kecil dan tidak mampu lagi menampung limpasan air ketika intensitas hujan tinggi sehingga jalan raya Cibadak mengalami genangan air sesaat. Debit banjir rencana (Qr) untuk 5 tahun sebesar $0,1257 \mathrm{~m}^{3} /$ det dengan kecepatan aliran 2,5meter/detik. Setelah itu menganalisis kapasitas tampung saluran eksisting crossing jalan raya Cibadak, didapatkan hasil sebesar $0,004875 \mathrm{~m}^{3} /$ det. Perhitungan ini menunjukan bahwa saluran eksisting sudah tidak dapat menampung debit banjir rencana.

Dari hasil evaluasi penulis merekomendasikan solusi untuk mengatasi masalah genangan di jalan raya Cibadak, seperti memperbesar dimensi saluran crossing jalan dari $\varnothing 40 \mathrm{~cm}$ atau 0,4 m menjadi $\varnothing 150 \mathrm{~cm}$ atau $1,5 \mathrm{~m}$ didapatkan hasil debit saluran sebesar $0,56 \mathrm{~m}^{3} /$ detik. Ini diperkirakan tidak akan banjir ketika intensitas hujan tinggi.

\section{DAFTAR PUSTAKA}

Akbar. 2019. Typical Drainase. Dinas Perumahan dan Kawasan Pemukiman

[BPS] Badan Pusat Statistik Kabupaten Sukabumi. 2018. Katalog: 1102001.3202Kabupaten Sukabumi Dalam Angka. 
[BPS] Badan Pusat Statistik Kabupaten Sukabumi. 2018. Katalog :1102001.302.220. KECAMATAN CIBADAK DALAM ANGKA 2017

[BSN] Badan Standardisasi Nasional. 1994. SNI. 03-3424-1994: Tata Cara Perencanaan Drainase Permukaan Jalan.

Chow, Ven Te, Terjemahan Oleh Rosalina, E.V.N. 1997. Hidrolika Saluran Terbuka. Terjemahan oleh Jakarta: Penerbit Erlangga.

Dinas Pengelolaan Sumber Daya Air. Curah Hujan Maksimum Bulanan

Suhendi.SUKABUMIUPDATE.COM. Banjir 35 Sentimeter Rendam Jalan Suryakencana Cibadak Sukabumi https://sukabumiupdate.com/detail/sukabumi/peristiwa/50612-Banjir 35 Sentimeter- Rendam-JalanSuryakencana-Cibadak. Diakses 19 April 2019

Hasmar, H.A. Halim. (2011). Drainase Terapan. Yogyakarta: UII Press.

Manullang, Pebrian Krisman. 2017. Evaluasi Sistem Drainase Jalan Raya (Studi Kasus: Jalan Nusantara Raya Perumnas 3 Kota Bekasi). [Skripsi]. Jakarta: Fakultas Teknik, Universitas Negeri Jakarta.

R. J Kodoatie, 2003 “Manajemen dan Rekayasa Infrastruktur”. Pustaka Pelajar. Yogyakarta

Suripin. (2004). Sistem Drainase Perkotaan yang Berkelanjutan. Yogyakarta: ANDI Offset.

Triatmodjo, Bambang. 2006. Hidrologi Terapan. Yogyakarta: Penerbit Beta Offset. 